\title{
THE ASSUMPTIONS OF SUCCESSFUL DEVELOPMENT OF RURAL TOURISM IN LITHUANIA (CASE STUDY OF EASTERN AUKŠTAITIJA REGION)
}

\author{
Vladimiras GRAŽULIS, Mykolas Romeris University, Valakupių g. 5, LT-10101 Vilnius, Lithuania, vladimirasg@takas.lt \\ Ramutė NARKŪNIENĖ, Utena University of Applied Sciences, Maironio g. 7, LT-28142 Utena, Lithuania, \\ ramutenarkuniene@gmail.com (corresponding author)
}

\begin{abstract}
Tourism is one of the activities in rural areas that creates added value, rapidly becomes a part of the global economic and social processes. The authors of the article have analysed the assumptions of successful development of rural tourism in Eastern Aukštaitija region. The article provides the thoughts and reflections of the scientists and researchers in the area of the topic being analysed. What assumptions have determined successful development of rural tourism in the region? The aim of the research is to perform the analysis of development of rural tourism in Eastern Aukštaitija region and to discuss the assumptions of successful development of rural tourism in this region. The objectives of the research include the performance of theoretical analysis of development of rural tourism and the execution of the situation analysis of rural tourism in Eastern Aukštaitija region. The following methods have been applied: the analysis of scientific references, quantitative research - survey and generalization of the questionnaire data. The article includes summarized results of the research that aims at determining the assumptions of successful development of rural tourism in Eastern Aukštaitija region. Successful development of rural tourism depends on external (economical, natural, legal, political, social and technological) and internal (the size of homesteads, the number of services, the experience of the owners of the homesteads in rural business, professional knowledge of the staff and the ability to communicate in a foreign language(s), etc.) factors.
\end{abstract}

Keywords: a tourist, a region, rural tourism, development of the rural tourism.

\section{INTRODUCTION}

Tourism is one of the activities in rural areas that is creating added value, and rapidly becoming a part of the global economic and social processes. By the data of EuroGites (European federation of rural tourism), there are 400 thousand rural tourism homesteads with 3.6 billion places. Rural tourism supports 900000 direct and indirect jobs in Europe, and generates 150 billion in gross income each year (EuroGites, 2009). Rural tourism became a 'creating tool' for many communities which are seeking to diversify their economies because of its ability to generate local employment, promote external investment and supplement traditional industries. Emerging of new types of services, rural tourism began a slow process of changing people's mentality (Cole, 2004).

Many scientists and researchers have analysed the tendencies of the development of rural tourism: A. I. Polo and D. Frías (Strategies of Rural Tourism, 2010), G. M. V. de la Torre, J. L. T. Herreros and E. M. Fernández (alternatives of rural tourism, 2010), R. Sharpley (sustainable development of rural tourism, 2015). To look at the dynamics of development of rural tourism homesteads in 2003-2012 in Lithuania, an uneven growth of rural tourism homesteads (except the boost in 2005-2006 from 398 rural tourism homesteads in 2005 till 531 rural tourism homesteads in 2006 and a lower growth in 2010) is observed Statistics Lithuania, 2005, 2006), which is reasonably associated with the supporting measures of the European Union Structural Funds for the development of rural tourism in 2004-2006 (Europen federation of rural tourism). $40.7 \%$ of the owners of rural tourism homesteads who participated in the survey made use of the EU support. The changes in the tourism business in Lithuania, i.e. the emerging of the new niche attracted the attention of the scientists and researchers of Lithuania to begin analysing the topic, for example, A. Žalys, I. Žalienè, I. Iždonaite (the policy of development of rural tourism, 2006), V. Žilinskas, M. Maksimenko (the perspectives of sustainable development of rural tourism, 2008), A. Damuliene (the financial support of the EU for rural tourism, 2009), A. Astromskienè (the evolution of rural tourism, 2010), J. Ramanauskienè, A. Gargasas (entrepreneurship of rural tourism, 2010), V. Gražulis, B. Žuromskaitė (the development of tourism infrastructure, motivation of tourists, 2011).

However, rural tourism is mostly studied in the overall context of service economy and tourism, by mostly highlighting the influence of rural tourism development and less often the factors which determine the development of

Copyright (C) 2015 The Authors. Published by Aleksandras Stulginskis University. This is an open-access article distributed under the terms of the Creative Commons Attribution License (CC-BY 4.0), which permits unrestricted use, distribution, and reproduction in any medium, provided the original author and source are credited. 
rural tourism business. The development of rural tourism is widely analysed on the national scale and the development problems of individual regions are not being addressed.

The object of the research: the assumptions of successful development of rural tourism in Eastern Aukštaitija region.

The aim of the research: to perform the analysis of the development of rural tourism in Eastern Aukštaitija region and discuss the assumptions of successful development of rural tourism in this region.

The following are the objectives of the research:

1. To perform theoretical analysis of the development of rural tourism.

2. To perform the analysis of the development of rural tourism in Eastern Aukštaitija region.

3. To discuss the assumptions of successful development of rural tourism in this region.

The analysis of scientific references, quantitative research - a survey and the generalization of the questionnaire data were applied in the research. Eastern Aukštaitija region was selected to perform a questionnaire survey since the region has the highest number of rural tourism homesteads in Lithuania. Two separate questionnaires were designed - one for the owners of rural tourism homesteads and another for visitors. The questionnaires have been placed at www.apklausa.lt.

The survey sample. The survey sample of the research was calculated according to the formula of Schwarze (18). The survey involved 52 owners of rural tourism homesteads (according to the formula a sufficient size to ensure the representativeness of the research sample is 48 respondents). The second survey involved 104 tourists (according to the formula a sufficient size to ensure the representativeness of the research sample is 66 respondents). The questionnaires were processed by applying Microsoft Excel application programme. The rural tourism homesteads which have participated in the survey are located in the following districts of Eastern Aukštaitija: Molètai (30.8\% of the homesteads), Zarasai (26.9\% of the homesteads), Anykščiai (19.2\% of the homesteads), Utena (11.5\% of the homesteads) and Ignalina ( $11.5 \%$ of the homesteads) districts. $67 \%$ of the homesteads were founded during the last 10 years. The research included a diverse range of rural tourism homesteads: the ones devoted for quiet, passive recreation $-37 \%$, for the family rest $-29 \%$, for active leisure $-16 \%$, for family celebrations $-14 \%$ and for corporate events $-4 \%$.

The article introduces a discussion in the form of discourse on the development of rural tourism issues and the findings of the research. According to the authors' opinion, the research can be referred to as a pilot study, opening the possibility for further scientific research.

\section{SCIENTIFIC DISCOURSE ON THE DEVELOPMENT OF RURAL TOURISM}

The definition "rural tourism" was adopted by the European Commission as a tool to describe and explain all the touristic activities in rural areas (European Commision). According to R. Sharpley and others (2015), rural tourism could be defined in the abstract, as a state of mind, and technologically, linking with activities, targets and other measurable characteristics. Lithuanian tourism professionals provide the following definition of rural tourism: rural tourism - it is a purposeful recreational activity of people who have arrived to rural areas and stay in the homesteads of rural tourism (Armaitienè and others, 1999).

As J. Matekonienè and others notes (2002) rural tourism provides opportunities for economic development of the community, to raise the standards of living, to protect the cultural heritage and social values. L. Pulido and E. Cardenas (2013) note that tourism can significantly contribute to the solution of rural problems such as unemployment, massive rural exodus, it creates and redistributes income, increases the involvement in activities, creates new jobs. The development of rural tourism can act as a precondition for the transformation of rural areas, ensuring the income for representatives of rural tourism businesses establishment of new small business enterprises and work placements (World Tourism Organization, 2002). According to R. Dapkus (2009) effective development of rural tourism is possible only with a balanced structure of all the levels of an organization and coordinated communication, so it is very important in the municipality of every district to have a tourism specialist responsible for the implementation of tourism policy. The European Parliament has defined guidelines for rural tourism - rural tourism must improve the quality of life, provide economic benefits and create jobs and prevent depopulation of rural areas (European Parliament, 2013).

V. Gražulis and B. Žuromskaitė (2011) propose to take into account the significance of the development of Lithuanian rural tourism in shaping the country's competitive advantages and to increase tourist interest in travelling to separate tourist regions, to solve a number of problems:

- Uneven position of homesteads in the municipalities, for example, less expensive accommodation away from the major tourism centre can become an alternative source of income for the owners of rural tourism homesteads;

- Expand nomenclature of tourism services in addition to the basic services (accommodation and meals), to offer new products which might be interesting for tourists.

In order to attract more visitors to rural tourism homesteads, the owners have to offer a wide range of services with its specialization (R. Sharpley and L. Pender, 2005). Providing specialized services of rural tourism is a particular challenge in order to increase the competitiveness of rural tourism. There are 10 main specializations of rural tourism: for quiet recreation, educational recreation, active recreation, rest with the family, the culinary heritage, nature-friendly country houses, health farmstead, family celebrations, corporate events, agro-tourism homesteads (The qualification requirements for rural tourism (by storks)). Rural tourism homesteads in Lithuania are classified according to the level of 
service and comfort by using the system of storks ( 1 stork - the lowest level, 5 storks - the highest level $)^{1}$ (The qualification requirements for rural tourism (by storks)).

V. J. Žilinskas and M. Maksimenko (2008) emphasize that the strength of rural tourism is the nation's material and spiritual heritage and its creative application in modern public environment. According to V. J. Žilinskas and M. Maksimenko (2008), for the development of rural tourism in Lithuania, it is necessary to analyse the favourable and negative development factors. If the exclusion of favourable factors is required for the development prospects of rural tourism, description of negative factors helps for objective assessment of the situation by permitting them to devise measures to eliminate or at least reduce the negative impact. According to D. Labanauskaite, V. Jusčius (2001) and I. Žalienè (2002) rural tourism is an alternative kind of activity allowing the creation of additional jobs and by 30-40 percent increasing income of the farmers from agriculture. According to V. J. Žilinskas and M. Maksimenko (2008) only those owners of rural tourism homesteads who live in rich recreational areas can be exclusively engaged in rural tourism business.

Scientific references (I. Vainienè, 2001, E. Vitkienè, 2002, and others) acknowledge that the development of rural tourism is influenced by internal and external factors. According to A. Armaitiene and others (1999) the internal factors, disturbing the development of rural tourism is the lack of professional knowledge, poor knowledge of foreign languages, imperfect organizational structure, poor facilities or equipment, lack of information, and shortage of experience.

To summarize the views and research results discussed in the references, the authors propose for scientific analysis the impact of external factors dimension on rural tourism development which is presented in Table 1.

Table 1 The external factors stimulating and restricting the development of rural tourism

\begin{tabular}{|c|c|c|}
\hline $\begin{array}{c}\text { Stimulating factors } \\
\end{array}$ & Factors & Restricting factors \\
\hline $\begin{array}{l}\text { The legislation in force to define the status of } \\
\text { rural tourism and development, etc. }\end{array}$ & Legal factors & $\begin{array}{l}\text { Influence of regulation of the protected areas on a } \\
\text { variety of exaggerated prohibitions }{ }^{2} \text {, etc. }\end{array}$ \\
\hline $\begin{array}{l}\text { The owners of homesteads have a possibility to } \\
\text { use the EU funding and to obtain additional } \\
\text { income. Favourable bank interest rates, etc. }\end{array}$ & Economic factors & $\begin{array}{l}\text { Shortage of recourses for investment, poor people's } \\
\text { income level, low financial opportunities of the } \\
\text { farmers who are engaged in rural tourism. } \\
\text { Unattractive banks' financing arrangement for rural } \\
\text { tourism business, etc. }\end{array}$ \\
\hline $\begin{array}{l}\text { Natural resources, e.g., a river, a lake, a forest, } \\
\text { beautiful landscape, beautiful nature, } \\
\text { favourable geographical location, etc. }\end{array}$ & Natural factors & $\begin{array}{l}\text { Influence of seasonality, unattractive location of } \\
\text { rural tourism homestead, etc. }\end{array}$ \\
\hline $\begin{array}{l}\text { Stable political situation in Lithuania and in the } \\
\text { EU. Agreements of the European Community } \\
\text { with the third countries regarding visa issue, } \\
\text { tourism-friendly policy, etc. }\end{array}$ & Political factors & $\begin{array}{l}\text { Tourism policy is not obligatory on the municipal } \\
\text { level; the funds are not allocated to implement } \\
\text { tourism policy, bad criminal situation in the country, } \\
\text { etc. }\end{array}$ \\
\hline $\begin{array}{l}\text { Training and counselling opportunities for rural } \\
\text { tourism businesses. The usage of nation's } \\
\text { material and spiritual heritage and its creative } \\
\text { application in modern public environment. } \\
\text { Cultural potential of the region, local traditions, } \\
\text { holidays and customs (e.g., St. Jonas' Festival, } \\
\text { Shrove Tuesday and other holidays), etc. }\end{array}$ & Social factors & $\begin{array}{l}\text { Mentality of rural families and overall social status }{ }^{3} \\
\text { of rural communities, relatively high unemployment } \\
\text { level, potential emigration of customers, shortage of } \\
\text { qualified personnel, etc. }\end{array}$ \\
\hline $\begin{array}{l}\text { A well-developed rural infrastructure and } \\
\text { quality of roads, e.g., roads with a good cover, } \\
\text { well-maintained at different seasons of the } \\
\text { year, high-speed internet, well-equipped } \\
\text { children's playing-fields and sports grounds, } \\
\text { landscaped recreation area, well-equipped } \\
\text { accommodation and utility facilities, etc. }\end{array}$ & Technological factors & $\begin{array}{l}\text { Insufficiently developed rural infrastructure, poor } \\
\text { access, not-installed or poorly maintained recreation } \\
\text { areas, accommodation and other facilities do not } \\
\text { meet the requirements, insufficient supply of } \\
\text { domestic water, inadequate sewage treatment, and } \\
\text { poor Internet connection, etc. }\end{array}$ \\
\hline
\end{tabular}

Source: composed by the authors of the article

The survey results confirm the affirmations in Table 1 - economic, legal, political, natural, social and technological factors can not only promote, but also limit the development of rural tourism.

\section{ANALYSIS OF THE ASSUMPTIONS FOR SUCCESSFUL RURAL TOURISM DEVELOPMENT IN EASTERN AUKŠTAITIJA REGION}

To present scientific discourse on the topic of rural tourism development, attention should be drawn to the fact that certain indicators describe the effectiveness of any economic activity. Such indicators in the business of rural tourism are the number of tourists, income from their visits, number of services and their cost, investments into business, number of accommodation places and so on. Figures 1 and 2 present the variation of the homestead activity indicators. The

\footnotetext{
${ }^{1}$ The survey involved $1,9 \%$ one stork, $9,6 \%$ two storks, $21,2 \%$ three storks, $19,2 \%$ four storks $1,9 \%$ five storks classified rural tourism homesteads.

${ }^{2}$ For example, restriction to build buildings in management plans of national parks (planning schemes) and general planning unidentified documents limit recreational constructions, while blocked development of rural tourism (4).

${ }^{3}$ A. Damuliené, 2009
} 
research involved 52 homesteads of rural tourism, 16 homesteads (30.8\%) have business experience up to 5 years and 36 homesteads $(69.2 \%)$ - more than 5 years. The homesteads with business experience up to 5 years make greater efforts to get involved in the competition for tourists. Within few years this group of homesteads have expanded their services and the number of places for nearly 1.5 times. Despite the jump in prices of the services, their achievements in attracting tourists are higher compared to the homesteads with more than 5 years of experience in this particular business.

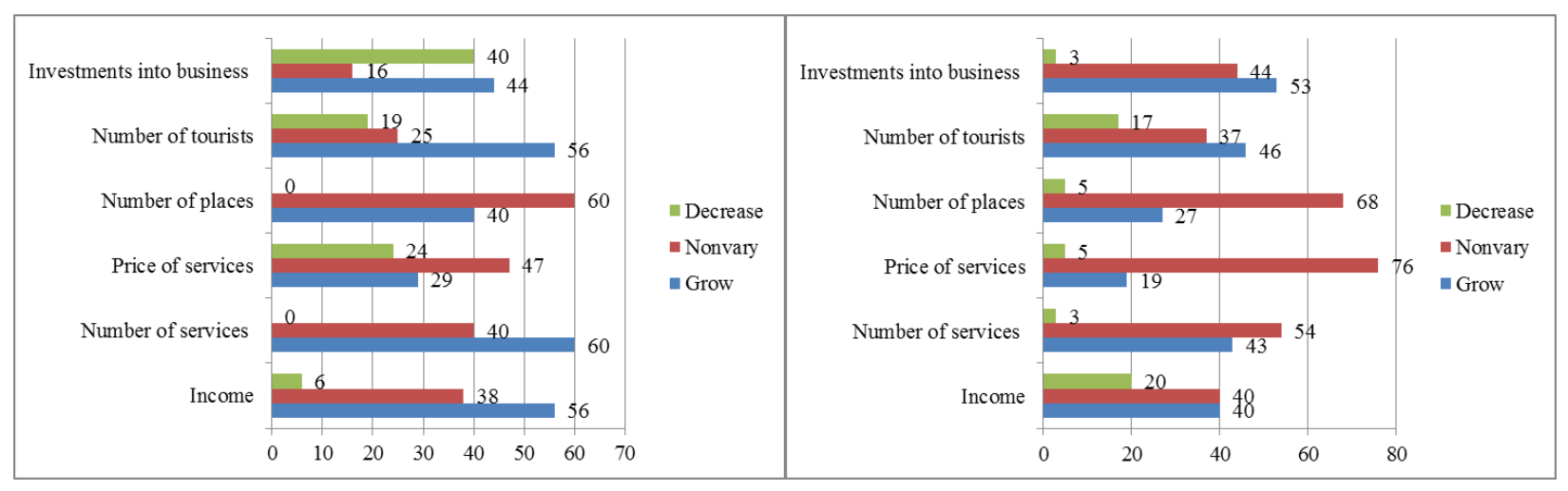

Figure 1 Variation of the activity indicators in rural tourism homesteads being in business up to 5 years

Source: composed by the authors of the article by results of survey
Figure 2 Variation of the activity indicators in rural tourism being in business for more than 5 years

Source: composed by the authors of the article by results of survey

According to the survey, in 2013 most of the visitors of the region's rural tourism were tourists from Lithuania (85\%), $15 \%$ - foreigners. A similar trend continued in 2014: respectfully $86 \%$ of tourists were from Lithuania and 14 $\%$ from abroad ${ }^{4}$. In 2013 and 2014 the main rural tourism visitors of Eastern Aukštaitija region were staying overnight visitors $^{5}$, who, as a rule, spend 2-3 days in rural tourism homesteads (see Table 2). The same tendency was in 2014.

Table 2 Distribution of tourists by duration of stay in homesteads of rural tourism, $\%$

\begin{tabular}{|l|c|c|c|c|}
\hline \multicolumn{1}{|c|}{ Visitors } & \multicolumn{2}{|c|}{ Visitors from Lithuania } & \multicolumn{2}{c|}{ Visitors from abroad } \\
\cline { 2 - 5 } & 2013 & 2014 & 2013 & 2014 \\
\hline One day visitors & 30 & 37 & 19 & 30 \\
\hline Staying overnight visitors (2-3 days) & 60 & 54 & 81 & 70 \\
\hline Staying overnight visitors (more than 3 days) & 10 & 9 & - & - \\
\hline
\end{tabular}

Source: composed by the authors of the article by results of survey

There were 1.5-2 times more staying overnight visitors for 2-3 days from Lithuania than one-day visitors and 6 times more than staying overnight here over 3 days. Foreign visitors staying overnight were greater in number than oneday visitors (4.2 times more than in 2013 and 2.3 times more than in 2014). Even $40.8 \%$ of the visitors of the homesteads indicated that they spend 2 days in rural tourism homesteads. To summarize, it may be stated that the main visitors in rural tourism homesteads in the region are those who stay for 2-3 days. It is obvious that the owners of homesteads before offering new services have particularly to focus on this group of tourists; at the same time promoting other groups of tourists to visit their homesteads. When expanding rural tourism business, the owners should constantly follow who are their customers, since the visitors' distribution by the arrival purpose depends on it. Table 3 shows the distribution of the visitors according to the purpose of their visit to the homesteads.

The tendencies according to the purpose of the visit are not stable among the visitors from Lithuania - in 2013 the largest number of tourists consisted of the tourists with special interests - $34 \%$, whereas in 2014 there were party participants $(39 \%)$.

Table 3 Distribution of the tourist by the groups and visit purposes in the homesteads of rural tourism, \%

\begin{tabular}{|l|c|c|c|c|}
\hline \multicolumn{1}{|c|}{ Groups of tourists/Visit purpose } & Visitors from Lithuania & \multicolumn{3}{c|}{ Visitors from abroad } \\
\cline { 2 - 5 } & 2013 & 2014 & 2013 & 2014 \\
\hline Older people / Peaceful recreation, recreational purposes, etc. & 20 & 28 & 50 & 50 \\
\hline $\begin{array}{l}\text { Groups of special interests / Participation in landscape recreation, } \\
\text { picnic, ride bikes, walk, etc. }\end{array}$ & 34 & 22 & - & 50 \\
\hline Learning Groups / Participation in conferences, seminars, etc. & 20 & 7 & 50 & - \\
\hline People with disabilities / Outdoor recreational purposes, etc. & 6 & 4 & - & - \\
\hline $\begin{array}{l}\text { Meeting participants / Participation in banquets (weddings, birthdays) } \\
\text { and company parties, etc. }\end{array}$ & 20 & 39 & - & - \\
\hline
\end{tabular}

Source: composed by the authors of the article by results of survey

\footnotetext{
${ }^{4}$ It should be noted that the situation in all the Lithuanian rural tourism homesteads does not differ very much - in 2014 there were $91 \%$ of the tourists from Lithuania and $9 \%$ from abroad (SD, 2014).

${ }^{5}$ Staying overnight visitors (according to the classification of the World Tourism Organization).
} 
Foreign tourists that stay in homesteads are older people $(50 \%)$ or they are visitors seeking for quiet recreation in the natural environment, the visitors for training purposes and special interest groups. As the results of the survey illustrate, foreign tourists to Eastern Aukštaitija homesteads of rural tourism come from Russia (17\%), Latvia (16\%), Germany (14 \%), Poland (11\%), Belarus (7\%), 5\% from Finland, Estonia and France, $4 \%$ - from Sweden and Denmark ${ }^{6}$, the visitors from other countries make $9 \%$ of the foreign visitors. Only $3 \%$ of the homesteads which participated in the survey did not receive foreign visitors at all. By the data of the Statistics Lithuania, in 2010, 13.2 thousand, in 2013 -25.4 thousand foreign visitors stayed and had rest in rural tourism homesteads of Lithuania. The survey shows that the personnel of rural tourism homesteads communicate in Russian (41\%), English (27 \%), Polish (12 \%), German (11\%), and $3 \%$ in Belarusian, Latvian and other languages. The third part of the owners of rural tourism homesteads (28\%), stress the importance of communication in foreign languages when they speak about the importance of the knowledge and abilities of their personnel. The question remains whether foreign language knowledge level in rural tourism business is sufficient in order to accept the environmental challenges? It is obvious that in order to expand the business internationally, a precondition of the ability to communicate in foreign languages must be met first. The presented results of the survey can be considered as a major obstruction to develop rural tourism business successfully.

The owners of rural tourism homesteads prioritized the strengths of their business development in the following way: the location of rural tourism homestead $(33 \%)$, the established infrastructure $(14 \%)$ and the variety of services in the homestead $(10 \%)$. The visitors of rural tourism homesteads indicated the location of rural tourism homestead (30\%) as the main option, but another rather important indicator to arrive for them is the price (14\%) and the variety of services in the homestead $(12 \%)$. As we can see, the main strength indicated both by the owners of rural tourism homesteads and visitors is the homestead's location (the lake and the presence of a great landscape are highly appreciated). Thus, these factors remain the most relevant in terms of rural tourism exclusivity. Various studies confirm the opinion of the survey respondents ${ }^{7}$. The variety of services, as well as the location of rural tourism homestead was rated the same by both the owners of rural tourism homesteads and visitors (the third place). As the main weaknesses of their business every fourth owner named their homestead's insufficient readiness to accept persons with disabilities $(27 \%)$, the imperfection of the existing infrastructure, in particular, poor communication and information tools to be used in the surrounding areas (24\%). For homestead visitors good accessibility to country houses and well-functioning communication are important as well.

According to the results of the survey, $43 \%$ of the homesteads of rural tourism are planning to expand their business, most of them are the owners of the homesteads classified as 3 and 4 storks. They plan to offer diverse entertainment for active and passive recreation, (sauna, horse riding, hiking around the area, water activities, fishing, etc.), every fourth-fifth homestead plans to increase the number of places (21\%), and to apply other measures to develop their business. According to the results of the survey, the visitors to rural tourism homesteads mostly lack greater variety of entertainment $(32.2 \%)$ and new packages of services $(28 \%)$.

\section{DISCUSSION}

The assumptions of successful development of rural tourism in Eastern Aukštaitija region are external and internal factors, which can influence successful development of rural business. The external factors by data of survey could be listed in priority order this way: economic (GDP, salary development, availability to use the EU support), political (political environment, visa, passport regime, customs, implementation of state tourism policy, criminogenic situation in the country), natural (natural environment and its application for recreational activities, seasonality), legal (legislation of rural tourism business), technological (rural infrastructure, accessibility by roads, water supply, access to the Internet)and social (demographics, lifestyle, celebration of the traditions and their change, medical assistance and training arrangements) factors. The internal factors are: the size of homesteads, the number of services, the experience of the owners of the homesteads in rural business, professional knowledge of the staff and their ability to communicate in a foreign language(s) and others. Among the internal factors, which can influence the successful development of rural tourism, the following ones should be mentioned: communication in a foreign language(s), attractive location of rural tourism homestead (homestead located near a lake or other water body surrounded by the beautiful landscape) and a variety of homestead services provided at different times of the year. The survey results show that external and internal factors can not only promote, but also can limit the development of rural tourism business.

\section{CONCLUSIONS}

Various scientists and researchers (A. I. Polo and D. Frías, R. Sharpley, A. Armaitienè, P. Grecevičius, A. Urbis, I. Vainiené and E. Vitkiene, and others) distinguish the assumptions of successful rural tourism development. The successful development of rural tourism depends on the external and internal factors. The survey results show that external and internal factors can influence successful development of rural business.

The survey results show, that the main visitors of rural tourism homesteads are the visitors who stay overnight and spend 2-3 days in rural tourism homesteads. Most of the visitors are the tourists from Lithuania, but a number of tourists

\footnotetext{
6 To compare the survey results in terms of foreigners who visited the Eastern Aukštaitija homesteads with the data of the Statistics Lithuania on the scale of the whole Lithuania (2014) a similar trend is observed - both homesteads in Lithuania and in Eastern Aukštaitija receive visitors from the same neighbouring countries.

${ }^{7}$ For example, according to I. Vainiene (2001), natural recreational resources are the basis for the development of rural tourism. Lakes which can be adapted for summer and winter recreation have the highest importance to the development of rural tourism in Lithuania.
} 
from abroad is increasing. The trends of visitors have been varying in recent years. A little less than a half of rural tourism homesteads plan to develop rural tourism. The owners of rural tourism homesteads, most of them are the owners of the homesteads which are classified by higher number of storks (3-4), plan to develop their rural tourism business. The owners of rural tourism homesteads plan to expand summer and winter activities, rent sports equipment, provide with health services and to organize camps, to organize educational services and to provide guiding services. By increasing the number of places in their homesteads and offering new services and entertainment activities, the owners of the homesteads can expect a successful business development, but it is not enough.

The assumptions of successful development of rural tourism in Eastern Aukštaitija region are external and internal factors, which can influence successful development of rural business. The external factors could be listed in priority order this way: economic, political, natural, legal, technological and social factors. Among the internal factors the following ones should be mentioned: communication in a foreign language(s), attractive location of rural tourism homestead (homestead located near a lake or other water body surrounded by the beautiful landscape) and a variety of homestead services provided at different times of the year.

\section{REFERENCES}

1. Armaitienė, A. Grecevičius, P. Urbis, A. Vainienė, I. 1999. Rural tourism. Vilnius: LTD „Valstiečiu laikraštis“. pp. 172 (In Lithuanian).

2. Astromskienè, A., Ramanauskienè, J., Gargasas, A., Vanagienè, V. 2010. The evolution of Lithuanian rural tourism business and the factors, influencing the changes. Nr. 1 (6), pp. 42-50 pp. Kaunas: Academia. (In Lithuanian).

3. Cole, S. 2014. Information and empowerment: the keys to achieving sustainable tourism.

4. Construction regulation improvement study of rural tourism. Regional Research Institute. 2004. Kaunas. Available at: www.ekoturtas.lt. (In Lithuanian)

5. Dapkus, R. 2009. The perspectives of tourism by local self-government level. Economics and Management: Current Issues and Perspectives, No. 3(16), pp. 60-72. In Lithuanian.

6. Damulienè, A. 2009. EU grants for rural tourism issues. Economics and Management: Current Issues and Perspectives, No. 3(16). 73-80. (In Lithuanian)

7. European parliament. Industrial heritage and agro/rural tourism in Europe. 2013.

8. European Commission. Available at: www.ec.europa.eu .

9. European federation of rural tourism. Available at: www.eurogites.org .

10. Gražulis, V., Žuromskaite, B. 2011. Lithuanian Countryside - is it Attractive Option for Tourists? Economics and Management: Current Issues and Perspectives, No. 4(24), pp. 135-147. (In Lithuanian)

11. Labanauskaitè, D., Jusčius, V. 2001. Concept and content of economic tourism product. Tiltai, No. 10. Transformation in Eastern Europe - Klaipèda: KU. (In Lithuanian)

12. Matekoniene, J. and others. 2002. Placement of rural tourism in continuous rural development. Development of regions - 2002. (In Lithuanian)

13. Nacional programme of development tourism in Lithuania Republic 2014-2020 year. Available at: https://www.etar.lt/portal/forms/legalAct.html?documentId=5a333640af3511e39b958c81fb177d0b. (In Lithuanian)

14. Opportunity study. Target investment in tourism development in the Eastern Aukštaitija (Utena county area). 2013. Vilnius. Available at: http://www.lietuvosregionai.lt/wp-content/uploads/2013/05/URTPGS-20130916.pdf(In Lithuanian)

15. Pender, L., Sharpley, R. 2005. The management of tourism. London: Sage Publication.

16. Polo, A. I. and Frías, D. 2010. Collective Strategies for Rural Tourism: The experience of networks in Spain. Journal of Tourism Consumption and Practice, Vol. 2, No.1, pp.25-45.

17. Pulido, J., Cardenas, P. 2013. Does tourism influence economic development? Journal of travel research.

18. Rudzkienė V. Social statistics. 2005. Vilnius: Publishing center of Mykolas Romeris Universitety. 260 p. (In Lithuanian)

19. Rural tourism and handicraft development in rural areas for 2007-2013 Program. Scientific research. Social and Economic Development Centre. Available at: www.tourims.lt/upload/Kaimo_TPP-galutinis_spausdinti.doc. (In Lithuanian)

20. Sharple, R. and others 2015. Tourism and development: Concept and issues.

21. Statistics Lithuania. Available at:http://osp.stat.gov.lt/informaciniai-pranesimai?articleId=3232216. (In Lithuanian)

22. The qualification requirements for rural tourism (by storks). Available at: http://www.atostogoskaime.lt/uploads/images/LKTA\%20dokumentai/lkta_klasifikaciniai_reikalavimai.pdf. (In Lithuanian)

23. Torre, G. M. V., Herreros, L. T., Fernández, E. M. 2010. Rural Tourism as an Alternative to the Development for Rural Areas and the Creation of Employment. International Journal of Humanities and Social Science, No.20.

24. Vainienè, I. 2001. Organization of rural tourism. Vilnius: Eugrimas. (In Lithuanian)

25. Vitkienè, E. 2002. Recreation. Klaipėda: S. Jokužis publishing - printing house. (In Lithuanian)

26. World Tourism Organization. Available at: http://www2.unwto.org/.

27. Žalys, L., Žalienè, I., Iždonaite, I. 2006. Characteristics of Lithuanian rural tourism and development policy. Economics and Management: Current Issues and Perspectives, No. 2(7). Pp. 180-179 pp. (In Lithuanian)

28. Žilinskas, V. J., Maksimenko, M. 2008. The perspectives of sustainability development. Nr. 7, pp. 214-224. (In Lithuanian) 